\title{
Association Between Leadership and Job Satisfaction Of Primary Health Centers in Denpasar
}

\author{
I N D E X I N G \\ Keywords: \\ Leadership; \\ Job Satisfaction \\ Primary Health Centers;
}

Made Karma Maha Wirajaya*

*Korespondensi Author: mdkarma.wirajaya@gmail.com

* Health Science Institute of Medika Persada Bali, Denpasar, Bali, Indonesia

\begin{abstract}
A B S T R A C T
Job satisfaction is very important because it can affect the behavior of employees working in the organization. Employees who are satisfied in the work will have positive behavior so they have a better performance. The preliminary study found that some employees are less satisfied with the supervisory aspects and attention of leader to employees. This study aims to determine the relationship between leadership and job satisfaction in primary health centers Denpasar. This research is a cross-sectional study, which involved75 samples. Samples were selected using total population sampling and analyzed using chi-square test. Most of employees perceived a lack in the leadership of primary health centers leaders $(52 \%)$ and satisfied with their work $(52 \%)$. The result of chi-square test shows that leadership with $\mathrm{OR}=12,01(95 \% \mathrm{CI}=4,02-35,89)$ is related to job satisfaction of primary health centers in Denpasar. Leader who are able to feel employees need can make employees feel satisfied for they work. Employees who are feel satisfied will give the best for the organization so can achieve its objectives. Most employees of primary health centers in Denpasar feel satisfied in work and leadership related to employees satisfaction in primary health centers in Denpasar.
\end{abstract}

Kepuasan kerja sangat penting karena dapat mempengaruhi perilaku pegawai dalam bekerja di sebuah organisasi. Pegawai yang puas dalam bekerja cenderung berperilaku postif sehingga memiliki kinerja yang lebih baik. Studi pendahuluan yang dilakukan didapatkan bahwa beberapa pegawai kurang puas terhadap aspek pengawasan yang dilakukan oleh pimpinan dan perhatian pimpinan terhadap pegawai. Penelitian ini bertujuan untuk mengetahui hubungan antara kepemimpinan dengan kepuasan kerja pegawai puskesmas di Kota Denpasar. Penelitian ini menggunakan design cross-sectional dengan 75 sampel yang diambil dengan total sampel dan dianalisis dengan chi-square. Sebagian besar pegawai puskesmas mempersepsikan kurang baik (52\%) kepemimpinan kepala puskesmas dan merasa puas dalam bekerja (52\%). Hasil uji chi-square mendapatkan bahwa kepemimpinan dengan OR=12,01 (95\% $C I=4,02-35,89$ ) berhubungan dengan kepuasan kerja pegawai puskesmas di Kota Denpasar. Kepemimpinan memiliki pengaruh yang besar terhadap keberhasilan organisasi. Pemimpin yang mampu merasakan apa yang dibutuhkan pegawai cenderung membuat pegawai merasa puas dalam bekerja. Pegawai yang merasa puas akan berusaha memberikan yang terbaik bagi organisasi agar organisasi tersebut mampu mencapai tujuannya. Sebagian besar pegawai puskesmas di Kota Denpasar merasa puas dalam bekerja dan kepemimpinan berhubungan dengan kepuasan kerja pegawai puskesmas di Kota Denpasar.

(C) 2018 JMMR. All rights reserved

Article history: Received 2018-Aug-31; Revised 2018-Sep-22; Accepted 2018-Dec-05

\section{INTRODUCTION}

The government has the responsibility to organize health development as an important part in achieving the national development goals. The development goals in the health sector are to increase awareness, willingness and ability to live healthy to achieve better health status in the community. Successful development in the health sector plays an important role in improving the quality of human

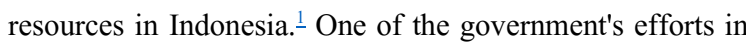
improving the health status of the community is to improve public access to health care through the provision of basic health facilities are most easily accessible by the public, namely primary health centers.

Primary health centers as first-rate facilities in providing health services to the public are required to have a good quality of health care. The demands and needs of the 
community for quality health services need to be addressed by improving the quality of human resources. Therefore, human resources in the health sector plays an important role as a driving source program. The role of human resources also establishes the health status of a country that can be seen in several health indicators. $\stackrel{2}{-}$ These conditions explain that the quality of human resources determines the quality of the process to be carried out so as to achieve a good goal attainment. This can be realized if the human resources are able to work better with high job satisfaction. . $^{-}$

Satisfaction is a positive feeling about someone's work which is the result of an evaluation of its characteristics. ${ }^{4}$ Employees who are satisfied with work have a high level of attendance and sometimes have better performance than unsatisfied employees..$^{5}$ Besides employees who are satisfied tend to have good performance, have lower absenteeism rates and a low desire to change job. Dissatisfied employees work more often daydreaming, lack of enthusiasm in work, quick fatigue, boredom, unstable emotions and unrelated activities. Besides that, the impact caused by dissatisfaction can be seen in the slow pace of employees at work, high level of absenteeism, negligence, low performance, low product quality and employee discipline issues. ${ }^{-}$It shows that job satisfaction is an important aspect for employees and organizations mainly because it is able to create a positive state in the organization environment. Job satisfaction can affect the work behavior of employees in organization. Therefore, the behavior of employees in the organization must be directed towards achieving the stated goals. Leaders in organization must be able to implement effective leadership in the sense of being able to encourage employees to achieve organizational goals without ignoring job satisfaction.

Denpasar has had a number of primary health centers are fairly evenly distributed in every district. Recorded in each sub-district at least there are two Primary health centers. Each primary health centers also has a very good human resources in terms of type and amount of personnel needed to provide services to the community. Based on the employee recap data of Health Department in Denpasar, the total number of health center staff is 565 employees consisting of 19 nutrition workers, 26 pharmaceutical workers, 251 nursing personnel, 35 public health workers, 78 doctors, 14 health analysts and 133 non-health workers. This condition requires the existence of better management and attention to employees, especially their job satisfaction. Based on the results of interviews with some employees at the primary health centers of Denpasar found that $57 \%$ of employees are less satisfied with the supervisory aspects undertaken by the leader and leader attention to employees. That conditions may indicate a problem related to the job satisfaction of the primary health centers employees.

Employee job satisfaction is influenced by several factors. One of the factors that plays an important role in creating employees job satisfaction is leadership. Based on the results of previous research conducted by Wibisono (2011), Hilatunnisa (2009) and Djestawana (2012) found that leadership has a close relationship and the most dominant factor in shaping job satisfaction..,$\frac{7,9}{-}$ Leaders in an organization must be able applying effective leadership in the sense of being able to encourage employees to achieve organizational goals without neglecting job satisfaction. Employees will feel satisfied when they feel they have been noticed and led well. Leaders who are able to feel what is employee needed tend to make employees feel satisfied in work. This research was conducted to know the relationship of leadership with job satisfaction of primary health centers employees in Denpasar.

\section{RESEARCH METHOD}

This research used cross sectional design with two research location that is in the Primary Health Centers II South Denpasar and Primary Health Centers III North Denpasar.

Table 1. The CSI of Primary Health Centers in Denpasar

\begin{tabular}{|c|c|c|c|c|}
\hline \multicolumn{4}{|c|}{ Primary Health Centers } & \multirow{2}{*}{$\frac{\text { CSI }}{86,29}$} \\
\hline $\begin{array}{l}\text { Primary } \\
\text { West }\end{array}$ & Health & Centers & I & \\
\hline $\begin{array}{l}\text { Primary } \\
\text { West }\end{array}$ & Health & Centers & II & 86,90 \\
\hline $\begin{array}{l}\text { Primary } \\
\text { East }\end{array}$ & Health & Centers & I & 84,58 \\
\hline $\begin{array}{l}\text { Primary } \\
\text { East }\end{array}$ & Health & Centers & II & 86,37 \\
\hline $\begin{array}{l}\text { Primary } \\
\text { North }\end{array}$ & Health & Centers & I & 84,07 \\
\hline $\begin{array}{l}\text { Primary } \\
\text { North }\end{array}$ & Health & Centers & II & 86,13 \\
\hline $\begin{array}{l}\text { Primary } \\
\text { North }\end{array}$ & Health & Centers & III & 83,30 \\
\hline $\begin{array}{l}\text { Primary } \\
\text { South }\end{array}$ & Health & Centers & I & 86,37 \\
\hline $\begin{array}{l}\text { Primary } \\
\text { South }\end{array}$ & Health & Centers & II & 87,81 \\
\hline $\begin{array}{l}\text { Primary } \\
\text { South }\end{array}$ & Health & Centers & III & 86,42 \\
\hline $\begin{array}{l}\text { Primary } \\
\text { South }\end{array}$ & Health & Centers I & IV & 83,58 \\
\hline
\end{tabular}


The primary health centers that was chosen as the research location was a public health center that had the highest and the lowest community satisfaction index (CSI). The highest CSI was at Primary Health Centers II South Denpasar and the lowest CSI namely Primary Health Centers III North Denpasar. CSI is used as an indicator of the level of work satisfaction at Denpasar public health centers because the CSI value can indicate that an organization has good performance, and good performance comes from employees who feel satisfied at work.

The sample is part of the population selected in a manner specific to the population.- ${ }^{-}$Samples that consisting of employees from primary health centers must be in accordance with inclusion and exclusion criteria. The inclusion criteria are:

1. All employees of primary health centers either civil or non-civil servant status

2. The employees of primary health centers that are willing to become respondents as evidenced by the signing of the consent form respondents

3. The employee of primary health centers who have worked at least one year

The exclusion criteria are:

1. The employees of primary health centers who served as a leader and night shift employees

2. The employees of primary health centers who are on leave or on study assignments

3. The employees who works at the main primary health center but is placed at a sub-district primary health center

The minimum sample size is calculated using the formula below.

\section{$\mathrm{n}=\quad \underline{\mathrm{z}^{2} 1-\alpha / 2} \mathbf{P}(\mathbf{1 - P}) \mathbf{N}$ $d^{2}(\mathrm{~N}-1)+Z^{2}$ 1- $/ / 2$ P (1-P)}

Information:

$\mathbf{n}$ : Minimum sample size that should be taken

Z 1- $\boldsymbol{\alpha} / \mathbf{2}$ : Standard deviation with 95\% CI of 1.96

$\mathbf{P}$ : Employees proportion of primary health centers who satisfied in job $0,433^{11}$

P (1-P) : Employees proportion of primary health centers who unsatisfied in job

D : Degree of precision that is $5 \%$

$\mathbf{N}$ : The number of selected population of primary health centers employees is 94 people

Based on the formula, it is found that the sample size is 75 employees. The sample consisted of 39 employees at Primary Health Centers II South Denpasar and 36 employees at Primary Health Centers III North Denpasar. Data were collected through interviews using a structured questionnaire which included a questionnaire of respondent characteristics including gender, age, status, number of dependents, education, occupation type, employment status and years of service; measured leadership of four dimensions including exemplary, motivator, information and communication and decision making and job satisfaction measured from five dimensions including competence, cooperation, achievement opportunity, more challenging job and working conditions. Perceptions of leadership are derived from a total score of 21 questions with good leadership categories (score $>42$ ) and poor leadership (score $<42$ ).

Job satisfaction is obtained from total score of 38 questions with satisfied category (score $>87$ ) and not satisfied (score <87). Data were analyzed using Stata SE 12.1 and processed as univariate and bivariate. The univariate is presented in the form of frequency distribution table on socio-demographic characteristics, leadership and job satisfaction.

Furthermore, bivariate analysis with chi-square is done to find out the relationship of leadership with job satisfaction of health center employees. This study has obtained ethical eligibility from the Ethics Commission of the Medicine Faculty of Udayana University/Sanglah General Hospital.

\section{RESULT AND DISCUSSION}

Respondents as many as 75 employees (100\%) have filled out the questionnaire completely.

Table 2. Sosio-Demographic Characteristic of Respondent on Primary Health Centers in Denpasar

\begin{tabular}{lcc}
\hline \multicolumn{1}{c}{$\begin{array}{c}\text { Sosio- } \\
\text { Demographic } \\
\text { Characteristic }\end{array}$} & $\begin{array}{c}\text { Frequency } \\
\text { (people) }\end{array}$ & Percentage (\%) \\
\hline $\begin{array}{l}\text { Gender } \\
\text { Male }\end{array}$ & 20 & $26,67 \%$ \\
Female & 55 & $73,33 \%$ \\
Age & & \\
$<42$ years & 35 & $46,67 \%$ \\
$>42$ years & 40 & $53,33 \%$ \\
Status & & \\
Single & 6 & $8 \%$ \\
Married & 69 & $92 \%$ \\
Number of & & \\
dependent & & \\
$<2$ people & 21 & $28 \%$ \\
$\geq 2$ people & 54 & $72 \%$ \\
Education & & \\
$<$ SMA & 25 & $33,33 \%$ \\
$>$ SMA & 50 & $66,67 \%$ \\
\hline
\end{tabular}


Table 2. (Continued) Sosio-Demographic Characteristic of Respondent on Primary Health Centers in Denpasar

\begin{tabular}{lcc}
\hline \multicolumn{1}{c}{$\begin{array}{c}\text { Sosio- } \\
\text { Demographic } \\
\text { Characteristic }\end{array}$} & $\begin{array}{c}\text { Frequency } \\
\text { (people) }\end{array}$ & Percentage (\%) \\
\hline $\begin{array}{l}\text { Occupation type } \\
\text { Health worker }\end{array}$ & 53 & $70,67 \%$ \\
$\begin{array}{l}\text { Non health worker } \\
\text { Employees status }\end{array}$ & 22 & $29,33 \%$ \\
Civil servants & 59 & $78,67 \%$ \\
Non civil servants & 16 & $21,33 \%$ \\
Years of service & & \\
$<6$ years & 27 & $36 \%$ \\
$\geq 6$ years & 48 & $64 \%$ \\
\hline
\end{tabular}

Description of socio-demographic characteristic of respondent on Primary Health Centers Denpasar can be seen from gender, age, status, number of dependent, education, occupation type, employees status and years of service. This description show in Table 2. It can be seen that most of the respondents are women as many as 55 people $(73.33 \%)$ while viewed from the age group, most respondents are age group $>42$ years that is 40 people $(53.33 \%)$. Based on the status, most of the respondents were married, 69 (92\%) and had more than two dependents, $54(72 \%)$ and viewed from education level, most of them had higher education level than senior high school that is 50 people $(66.67 \%)$. It can be seen from the occupation type and employment status, most of the respondents are health workers that is 53 people $(70.67 \%)$ and the status as civil servants are as many as 59 people $(78.67 \%)$. In addition, from the period of work, most of the respondents have more than six years working period that is 48 people $(64 \%)$.

Based on table 3 above, it can be see from the gender, most of responden are women both in Primary Health Centers II South Denpasar (69.23\%) and Primary Health III North Denpasar (77.78\%). Based on the age, most responden are age group $<42$ Years $(56.41 \%)$ in Primary Health Centers II South Denpasar and the most responden in Primary Health Centers III North Denpasar are age group $>42$ Years $(63.89 \%)$. Based on the status, most of the employees were married in Primary Health Centers II South Denpasar (87.18\%) and Primary Health Centers III North Denpasar (97.22\%).

Based on the number of dependents, most have a number of dependents $>2$ people in Primary Health Centers II South Denpasar (61.54\%) and Primary Health Centers III North Denpasar (83.33\%). Based on the education, most have an education level> high school in Primary Health
Centers II South Denpasar (66.67\%) and Primary Health Centers III North Denpasar (66.67\%). Based on occupatin type, most of the employees were health workers in Primary Health Centers II South Denpasar (71.79\%) and Primary Health Centers III North Denpasar (69.44\%). Based on the employees status, most of the employees are civil servants in Primary Health Centers II South Denpasar (74.36\%) and Primary Health Centers III North Denpasar $(83.33 \%)$. Based on work of period, most of the employees have $<6$ years working period (53.85\%) in Primary Health Centers III North Denpasar and most of the employees have $>6$ years $(83.33 \%)$ working period in Primary Health Centers III North Denpasar.

Table 3. Comparison of Sosio-Demographic Characteristic Respondent on Primary Health Centers II South and North III Denpasar

\begin{tabular}{|c|c|c|c|c|}
\hline \multirow[t]{2}{*}{$\begin{array}{c}\text { Sosio- } \\
\text { Demographic } \\
\text { Characteristic }\end{array}$} & \multicolumn{2}{|c|}{$\begin{array}{l}\text { Primary Health Centers } \\
\text { II South Denpasar }\end{array}$} & \multicolumn{2}{|c|}{$\begin{array}{c}\text { Primary Health } \\
\text { Centers III North } \\
\text { Denpasar }\end{array}$} \\
\hline & Frequency & $(\%)$ & Frequency & $(\%)$ \\
\hline \multicolumn{5}{|l|}{ Gender } \\
\hline Male & 12 & $30,77 \%$ & 8 & $22,22 \%$ \\
\hline Female & 27 & $69,23 \%$ & 28 & $77,78 \%$ \\
\hline \multicolumn{5}{|l|}{ Age } \\
\hline$<42$ years & 22 & $56,41 \%$ & 13 & $36,11 \%$ \\
\hline$>42$ years & 17 & $43,59 \%$ & 23 & $63,89 \%$ \\
\hline \multicolumn{5}{|l|}{ Status } \\
\hline Single & 5 & $12,82 \%$ & 1 & $2,78 \%$ \\
\hline Married & 34 & $87,18 \%$ & 35 & $97,22 \%$ \\
\hline \multicolumn{5}{|l|}{$\begin{array}{l}\text { Number of } \\
\text { dependent }\end{array}$} \\
\hline$<2$ people & 15 & $38,46 \%$ & 6 & $16,67 \%$ \\
\hline$\geq 2$ people & 24 & $61,54 \%$ & 30 & $83,33 \%$ \\
\hline \multicolumn{5}{|l|}{ Education } \\
\hline$\leq \mathrm{SMA}$ & 13 & $33,33 \%$ & 12 & $33,33 \%$ \\
\hline$>$ SMA & 26 & $66,67 \%$ & 24 & $66,67 \%$ \\
\hline \multicolumn{5}{|l|}{$\begin{array}{l}\text { Occupation } \\
\text { type }\end{array}$} \\
\hline Health worker & 28 & $71,79 \%$ & 25 & $69,44 \%$ \\
\hline $\begin{array}{l}\text { Non health } \\
\text { worker }\end{array}$ & 11 & $28,21 \%$ & 11 & $30,56 \%$ \\
\hline \multicolumn{5}{|l|}{$\begin{array}{l}\text { Employees } \\
\text { status }\end{array}$} \\
\hline Civil servants & 29 & $74,36 \%$ & 30 & $83,33 \%$ \\
\hline $\begin{array}{l}\text { Non } \quad \text { civil } \\
\text { servants }\end{array}$ & 10 & $25,64 \%$ & 6 & $16,67 \%$ \\
\hline $\begin{array}{l}\text { Years } \\
\text { service }\end{array}$ & & & & \\
\hline$<6$ years & 21 & $53,85 \%$ & 6 & $16,67 \%$ \\
\hline$\geq 6$ years & 18 & $46,15 \%$ & 30 & $83,33 \%$ \\
\hline
\end{tabular}

Research conducted by Hilatunnisa (2009) also obtained the same results related the characteristics of the research respondent, most of respondent were female health 
workers and had diploma and undergraduate degrees. Most respondent had a long working period of $13-16$ years..$\stackrel{8}{\text { This }}$ shows that most of the employees who work at primary health centers are educated and have a long working period so they have better experience working in the organization. This research also find the most employees belong to the productive age group, 36-45 years. This shows that most health centers are experienced employees. In a study conducted by Sukrajap (2016) it was also found that most of the employees were female and also showed that the majority of employees were productive age groups of 36-45 years. This shows that the majority of employees working in the health sector are female employees and generally working workers are of productive age. $\frac{12}{}$

The overview of leadership on Primary Health Centers in Denpasar can be seen from examplery, motivator, information dan communication dan decision making. This description shows in Table 4. In table 4, shows that the perception of leadership of primary health centers leader which is seen from exemplary mostly perceives good that is $64 \%$ and perception on ability of leader motivation to employees which seen from motivator indicator mostly perceives not good that is $64 \%$. Judging from leader ability of information and communication, mostly perceive good that is $92 \%$. Moreover perception in terms of decisionmaking, largely perceive good that is $69.33 \%$. Overall, the perception of primary health center employees toward the leadership is categorized as unfavorable that is $52 \%$.

Table 4. The Overview of leadership on Primary Health Centers in Denpasar

\begin{tabular}{lcc}
\hline \multicolumn{1}{c}{ Leadership } & $\begin{array}{c}\text { Frequency } \\
\text { (people) }\end{array}$ & $\begin{array}{c}\text { Percentage } \\
\text { (\%) }\end{array}$ \\
\hline Examplery & 48 & $64 \%$ \\
Good & 27 & $36 \%$ \\
Not Good & & \\
Motivator & 27 & $36 \%$ \\
Good & 48 & $64 \%$ \\
Not Good & & \\
Information and Communication & 69 & $92 \%$ \\
Good & 6 & $8 \%$ \\
Not Good & & \\
Decision Making & 52 & $69,33 \%$ \\
Good & 23 & $30,67 \%$ \\
Not Good & & \\
Overall Leadership & 36 & $48 \%$ \\
Good & 39 & $52 \%$ \\
Not Good & & \\
\hline
\end{tabular}

The following table compares the leadership of Primary Health Centers II South Denpasar and Primary Health Centers III North Denpasar. The results can be see in the table below.
Table 5. Comparison Leadership of Head Primary Health Centers in Denpasar

\begin{tabular}{|c|c|c|c|c|}
\hline \multirow{3}{*}{ Leadership } & Primary & Health & Primary & Health \\
\hline & $\begin{array}{l}\text { Centers II } \\
\text { Denpasar }\end{array}$ & South & $\begin{array}{l}\text { Centers III } \\
\text { Denpasar }\end{array}$ & North \\
\hline & Frekuensi & $\%$ & Frekuensi & $\%$ \\
\hline Good & 9 & $23,08 \%$ & 27 & $75 \%$ \\
\hline Not Good & 30 & $76,92 \%$ & 9 & $25 \%$ \\
\hline
\end{tabular}

In table 5 shows that in Primary Health Centers II South Denpasar only a few employees who perceive leadership is good (23.08\%) and the employees most perceive leadership is not good $(76,92 \%)$. Most of the employees perceive the leadership is good $(75 \%)$ in Primary Health Centers III North Denpasar.

The overview of job satisfaction on Primary Health Centers in Denpasar can be seen form competense, cooperation, achievement opportunities, more challenging jobs and working condition. In table 6 , in term from the aspect of competence, most of the employees feel satisfied that is $50.67 \%$ and seen from cooperation aspect, most of the employees also feel satisfied that is $66.67 \%$. Viewed from the aspect of achievement opportunity, most felt satisfied that is $56 \%$ including in terms of more challenging jobs, most also feel satisfied that is $86.67 \%$. Judging from the working conditions, most felt satisfied that by $64 \%$. Overall, the satisfaction of work perceived by primary health centers employees is in the satisfied category that is $52 \%$.

Table 6. The Overview of Job satisfaction on Primary Health Centers in Denpasar

\begin{tabular}{lcc}
\hline \multicolumn{1}{c}{ Job Satisfaction } & $\begin{array}{c}\text { Frequency } \\
\text { (people) }\end{array}$ & $\begin{array}{c}\text { Percentage } \\
\text { (\%) }\end{array}$ \\
\hline Competense & 38 & $50,67 \%$ \\
Satisfied & 37 & $49,33 \%$ \\
Not satisfied & & \\
Cooperation & 50 & $66,67 \%$ \\
Satisfied & 25 & $33,33 \%$ \\
Not satisfied & & \\
Achievement Opportunities & 42 & $56 \%$ \\
Satisfied & 33 & $44 \%$ \\
Not satisfied & & \\
More Challenging jobs & 65 & $86,67 \%$ \\
Satisfied & 10 & $13,33 \%$ \\
Not satisfied & & \\
Working Condition & 48 & $64 \%$ \\
Satisfied & 27 & $36 \%$ \\
Not satisfied & & \\
Overall Job Satisfaction & 39 & $52 \%$ \\
Satisfied & 36 & $48 \%$ \\
Not satisfied & & \\
\hline
\end{tabular}


The result of comparison job satisfaction of Primary Health Centers in Denpasar can be see from the table below.

Table 7. Comparison Job Satisfaction of Primary Health Centers in Denpasar

\begin{tabular}{|c|c|c|c|c|}
\hline \multirow{4}{*}{$\begin{array}{c}\text { Job } \\
\text { Satisfaction }\end{array}$} & Primary & Health & Primary & Health \\
\hline & Centers & South & Centers III & North \\
\hline & Denpasar & & Denpasar & \\
\hline & Frekuensi & $\%$ & Frekuensi & $\%$ \\
\hline Satisfied & 16 & $41,03 \%$ & 23 & $63,89 \%$ \\
\hline Not satisfied & 23 & $58,97 \%$ & 13 & $36,11 \%$ \\
\hline
\end{tabular}

In table 7 shows that more employees are satisfied (63.89\%) in Primary Health Centers II South Denpasar and more employees are satisfied too in Primary Health Centers III North Denpasar (41.03\%).

In table 8 , presented bivariate analysis of relationship between leadership with job satisfaction of primary health centers employees in Denpasar. The result of chi-square test shows that leadership variable with $\mathrm{OR}=12.01(95 \% \mathrm{CI}=$ 4.02-35.89) is related to job satisfaction of primary health centers employees in Denpasar. The results of bivariat analysis of leadership with job satisfaction on Primary Health Centers in Denpasar can be see from the table below.

Table 8. Bivariat Analysis of Leadership with Job satisfaction on Primary Health Centers in Denpasar

\begin{tabular}{|c|c|c|c|c|c|}
\hline \multirow[b]{2}{*}{$\begin{array}{c}\text { Independent } \\
\text { Variable }\end{array}$} & \multicolumn{2}{|c|}{ Job Satisfaction } & \multirow[b]{2}{*}{ OR } & \multirow[b]{2}{*}{$\begin{array}{c}95 \% \\
\text { CI }\end{array}$} & \multirow[b]{2}{*}{$\begin{array}{c}\mathbf{P} \\
\text { value* }\end{array}$} \\
\hline & $\begin{array}{c}\text { Satisfied } \\
\mathbf{f}(\%)\end{array}$ & $\begin{array}{c}\text { Not satisfied } \\
\mathbf{f}(\%)\end{array}$ & & & \\
\hline \multicolumn{6}{|l|}{ Leaders-hip } \\
\hline Not Good & $10(25,64 \%)$ & $29(74,36 \%)$ & Ref & & \\
\hline Good & $29(80,56 \%)$ & $7(19,44 \%)$ & 12,01 & $4,04-35,89$ & $<0,001$ \\
\hline
\end{tabular}

*statistic test with chi-square

Job satisfaction is the attitude of employees to work within an organization. A satisfied employee is likely to show a positive attitude towards his job but unsatisfied employees will have a negative attitude towards his work. One of the impacts of job satisfaction that felt by employees is the performance of good work. Good performance in providing health services will make people become satisfied. $\frac{13}{}$

The description of work satisfaction of Primary Health Centers in Denpasar is represented by Primary Health Centers II South Denpasar and Primary Health Centers III North Denpasar which the selection is based on the CSI value as an indicator of the level of employees work satisfaction at Denpasar public health centers. The highest CSI value was found in Primary Health Centers II South Denpasar, while the lowest CSI value was in Primary Health Centers III North Denpasar.

These results indicate that the community is more satisfied with the services provided by employees of the Primary Health Centers II South Denpasar compared to the Primary Health Centers III North Denpasar. A satisfied person shows an indication that employees are satisfied at work. This condition also shows that employees work satisfaction is higher in Primary Health Centers II South Denpasar compared to Primary Health Centers III North
Denpasar. However, the results of the study found that most employees felt dissatisfied when working in Primary Health Centers II South Denpasar (58.97\%) while the majority of satisfied employees worked at Primary Health Centers III North Denpasar (63.89\%). This result is different from the assumptions of previous researchers that the high community satisfaction also shows the high work satisfaction for employees. This condition shows that a satisfied community does not always indicate that employees are also satisfied at work.

The assumption of the researchers that the status of Primary Health Centers II South Denpasar as an ISO primary health centers also affects the work satisfaction of its employees. Basically, the aim of ISO is to create a primary health centers that is able to provide quality health services so as to provide satisfaction to the community. But there are several work standards that must be met and obeyed by all of public health center employees. This condition results in ISO-based primary health centers that have different workloads from health centers that do not have ISO certification. Increased workload due to several additional activities such as routine ISO meetings, recording and reporting activities. This will make employees feel dissatisfied at work Judging from the characteristics of age and working period, most of the 
employees are in the young age category, which is $<42$ years $(56.41 \%)$ and have a long service life of $<6$ years $(53.85 \%)$.

Employees who are young and have a long working period tend to have high expectations for their work so that if there are some aspects of work that are lacking, employees will tend to be dissatisfied. This opinion was confirmed by Glen in Davis (1997) who argued that young employees have high expectations and poor adjustments. Luthans in Mustar (1999) also mentions that employees who have just worked or are classified as new employees have low work satisfaction compared to employees who have long worked because new employees tend to have high expectations for their work. In addition, it was also found that most employees considered poor leadership (76.92\%), had low work motivation (61.54\%) and considered that the compensation received was inadequate (56.41\%).

The head of the primary health centers will certainly maintain the status of the public health center as an ISO public health center so there are likely to be some changes in the way and style of leadership undertaken. The increase in workload and lack of appreciation for the work achieved so far in improving the image of the public health center makes employees feel less motivated at work and feels that the compensation received is inadequate when compared to the workload being worked on. This condition will cause dissatisfaction at work. The impact that will be caused is that employees do not have enthusiasm at work, feels fatigue, get bored, emotions are unstable and do activities that have nothing to do with work. ${ }^{\text {? }}$

Different results were found at the Primary Health Centers III North Denpasar. Although the CSI value is lower than the Primary Health Centers II South Denpasar, it turns out that most employees feel satisfied at work (63.89\%). The assumption of the researchers that Primary Health Centers III North Denpasar is not an ISO primary health centers so that the workload of employees does not increase. Employees feel more comfortable at work because there are no additional activities such as the public health centers with ISO status. Judging from the characteristics of age and years of service, most employees are in the old age group that is $>42$ years $(63.89 \%)$ and have a long service life $>6$ years $(83.33 \%)$.

Employees who are older and have a long service life have better work experience and can also adjust to working conditions and situations. Glen in Davis (1997) explains that the more age work satisfaction will increase because expectations will decrease and have experience in work.
Cherrington (1994) states that there are two reasons why older workers are more satisfied, namely better selfassurance and strong work values so that they have high self-confidence in work. High self-confidence will give satisfaction in working because the work will be done happily so that the work will be good.

Greenberg and Baron (1997) also suggested that more experienced employees tend to have higher work satisfaction than employees who are less experienced. In addition, employee perceptions of leadership carried out by the head of the public health center are classified as good (75\%). This condition shows that the head of the public health center has been able to set a good example, be able to motivate employees, provide clear and easy-tounderstand information and communication and make appropriate decisions on the problems that exist. This will encourage public health center employees to work better which can be seen in the motivation of health center staff who are included in the high motivation category (75\%).

Employees who have high motivation tend to work in accordance with work procedures, high morale at work, a little complaining and obeying the leader's orders..$^{14}$ Judging from the compensation received, most also perceived adequately $(63.89 \%)$. Workloads that match compensation received also influence employees satisfaction in work. The existence of good leadership, high motivation in work and adequate compensation received by employees makes employees feel satisfied at work.

The results of this study found that most of primary health centers employees in Denpasar are satisfied in working (52\%). The results of this study are in line with the research conducted by Hilatunnisa Year 2009 in three primary health centers in Tangerang which found that most employees feel satisfied to work. ${ }^{8}$ In addition, the results of this study are in line with the Wibisono (2008) research at Primary Health Centers Turen Malang and Sudarsono (2010) at Primary Health Centers Sumbermanjing Wetan Malang who found that most employees feel satisfied working in primary health centers. . $^{7}, \underline{15}$

Organizations with more satisfied employees tend to be more effective than organizations with less-satisfied employees. A satisfied employee will be able to increase patient satisfaction. This happens because in service organizations, customer satisfaction lies in the way employees relate to their patients in providing services. A satisfied employee will show good performance as more friendly and responsive to his patients. In addition, satisfied employees are less likely to move so that patients will often 
encounter familiar and experienced employees. It can build patient satisfaction with an organization. $\underline{13}$

Job satisfaction is the attitude of employees towards work within an organization. Satisfied employees tend to show a positive attitude towards their work but employees who feel dissatisfied will have a negative attitude towards their work. In addition, it is also explained that employees who work not only focus on the tasks that are their responsibility but require social relationships with coworkers including leaders, compliance with policies and regulations that apply and meet performance standards. This shows that job satisfaction is influenced by several things, namely the work itself, coworkers, relationships with leaders, promotion and work environment. $\frac{16}{}$ Job satisfaction is influenced by several things, but generally affecting job satisfaction is satisfaction related to the work itself, recognition, compensation, relationships with leaders and opportunities for achievement. $\frac{17}{}$

The results of this study found that leadership correlates significantly with job satisfaction of primary health centers employees that is good leadership has 12.01 times greater chance to be satisfied than the primary health centers employees who have perception that the leadership is not good enough. The results of this study are in line with research conducted by Hilatunnisa in 2009 at three primary health centers in Tangerang, Wibisono in 2011 at Primary Health Centers Turen Malang and Djestawana in 2012 at 10 primary health centers in Denpasar. $\frac{7.8,9}{}$

The leaders of primary health centers have a very important role in regulating and managing all activities in primary health centers including employees. The leadership has a great influence on organizational success. This is because all forms of management activities at the primary health centers level both planning, implementation and supervision of primary health centers activities are managed and managed by the leaders of primary health centers. ${ }^{1}$

One of the leader's behaviors that can influence employees in work is exemplary. Exemplary is required by the leader so that the employees obey the rules that have been established together. $\frac{18}{}$ A leader in the organization must be able to provide good examples, commendable attitudes and behaviors that are role models for employees. Good leaders must be able to foster feelings of participation and responsibility for their work so as to increase employee morale. $\frac{19}{}$

The result of the research shows that the perception of the employees toward the leader of primary health centers in Denpasar is good (64\%). This condition indicates that the leader of the primary health centers has been able to provide a good role model for employees in the work. Exemplary demonstrated by a leader shows a leader's belief in all forms of activity plans to achieve organizational goals. Therefore leaders in the organization must be able to provide good examples, attitudes and behaviors praised for the employees. $\frac{19}{}$

An employee also needs to be motivated primarily by a leader. Providing motivation by the leader basically aims to achieve job satisfaction so as to improve employee performance in work. Motivating employees either directly or indirectly will generate the potential they have so that the employee has an effort to achieve personal and organizational goals effectively and efficiently. $\cdot \frac{18}{-}$

The result of the research shows that employee's perception toward leader's motivation ability is seen from motivator indicator is not good enough (64\%). This condition indicates that the ability of the leader is still lacking in motivating employees so that it may lead to dissatisfaction in work. The impacts caused by not satisfaction in the work of the slow employees in work, negligence, low achievement, the low quality of service provided and employees become less discipline. ${ }^{-}$Therefore, motivation is important because the leader needs a good cooperation with employees in carrying out tasksorganizational tasks to achieve organizational goals. $\underline{\underline{20}}$

In addition to exemplary and the ability to motivate employees, a leader must also have the ability in information and communication. Information obtained may come from inside and outside the organization. Information from inside organization is related to the task of supervisory leader so as to obtain important information related to employee's work while outside information relates to information from network of primary health centers that influence to activity of primary health centers. Therefore, in conveying information, leaders need to have effective communication skills that are clear and easy to understand..$\underline{17}$

A leader must continue to monitor the environment of the organization including the work done by employees. This is so that the leader is able to collect important information related to employee work. Information obtained by the leader must be used jointly and distributed to employees. The ability to convey information is related to the communication skills of leaders to their employees. .11 The ability to communicate is a manifestation of leadership behavior that will be seen in the delivery of information that is clear and easily understood by its employees. $\frac{18}{}$

The results of the study found that employee perceptions on information and communication indicators 
are good (92\%). These conditions indicate that the information and communication process has been running well. Good communication will support employees in completing their work so as to create a positive atmosphere in the organization and able to create job satisfaction. ${ }^{\text {? }}$

Decision-making means that leaders have a role as policy makers to be taken in the form of steps in solving problems or design an activity. Decision-making by leaders at the primary health centers level is generally done by deliberation, which means taking into account the opinions of employees in the organization.

The ability to make quality decisions is also a form of leader behavior. Decision making is the creation of events that involve an event by determining a choice or direction of a particular action..$^{2}$ The organization's vision and mission in relation to leadership is seen as innovation in the process of carrying out leadership tasks. The vision and mission of the organization is very important in its role in the decision-making process for leaders including in determining policies and determining organizational strategies. Vision is one of the key attributes of leadership and also serves as a guideline for every member of the organization in their activities. $\frac{18}{}$

The result of the research shows that employee perception on decision making indicator is good (69.33\%). These conditions indicate that the decision made by the leader of the primary health centers has been running well. Most organizational employees want an opportunity to participate in decision making. Increased participation in decision making will increase the membership of the organization. This participation will contribute positively to solving organizational problems as they will better understand the goals and objectives of the organization, the issues they are facing and their relationship to their work so that they are motivated to be creative in thinking about alternative solutions that will ultimately increase their job satisfaction. ${ }^{-}$

A leader is expected to implement effective leadership that is able to move employees to achieve goals together without ignoring the satisfaction of his work. Employees will feel satisfied when they feel they have been noticed and led well. Leaders who are able to feel what is needed employees tend to make employees feel satisfied in working. A satisfied employee will try to give the best for the organization so that the organization is able to achieve its objectives. The statement was reinforced by Sasongko (2008) that leaders who are able to apply good leadership will make employees feel satisfied that ultimately able to improve their performance towards more productive so that the goals set by an organization can be achieved..$^{22}$ The condition is highly dependent on the role of leaders in establishing relationships with employees, rewarding employees, developing and empowering employees. $\stackrel{24}{-}$

\section{CONCLUSION}

Most of primary health centers employees feel satisfied in their work and leadership related to job satisfaction of primary health centers employees in Denpasar.

Organizations with more satisfied employees tend to be more effective than organizations with less-satisfied employees. A satisfied employee will be able to increase patient satisfaction. This happens because in service organizations, customer satisfaction lies in the way employees relate to their patients in providing services. A satisfied employee will show good performance as more friendly and responsive to his patient.

The leaders of primary health centers have a very important role in regulating and managing all activities in primary health centers including employees. The leadership has a great influence on organizational success

Required efforts to improve the management capability of primary health centers leaders and pay attention to employee working conditions so as to create job satisfaction.

\section{ACKNOWLEDGMENT}

The researchers would like to thank to the lecturer friends of the health management information program of medical science Persada Bali who have provided encouragement and technical support for the preparation of this manuscript.

\section{REFERENCE}

1. Kementerian Kesehatan, 2004. Keputusan Menteri Kesehatan Republik Indonesia Nomor 128/MENKES/SK/II/2004 Tentang Kebijakan Dasar Pusat Kesehatan Masyarakat

2. Misnaniarti, 2010. Aspek Penting Pengembangan Dan Pemberdayaan Sumber Daya Manusia (SDM) Kesehatan Di Era Desentralisasi. Jurnal Ilmu Kesehatan Masyarakat, 1(1), pp.12-19.

3. Djestawana, I.G.G., 2012. Pengaruh Pengembangan Organisasi, Kepemimpinan, Jenjang Karir terhadap Kepuasan Kerja dan Kinerja Pegawai Puskesmas. Jurnal Kesehatan Masyarakat Nasional, 6(6), pp.261265. 
4. Robin, Stepent P. dan Timoty A. Perilaku Organisasi, Jakarta: Salemba Empat

5. Handoko, T.H., 2001. Manajemen Personalia dan Sumber Daya Manusia Cetakan Ke., Yogyakarta: BPFE

6. David, R., 2011. Organization Behaviour, Concept, Controversies, Aplications Eight Edit., New Jersey: Pretice-Hall International. Inc.

7. Wibisono, A., 2011. Pengaruh Iklim Organisasi terhadap Kepuasan Kerja (Studi tentang Pengaruh Iklim Organisasi terhadap Kepuasan Kerja Pegawai Puskesmas Turen di Malang). Jurnal Aplikasi Manajemen, 9(3), pp.1000-1010

8. Hilatunnisa, 2009. Pengaruh Kepemimpinan dan Tuntutan Tugas melalui Kepuasan Kerja terhadap Kinerja pegawai di Tigas Puskesmas Perawatan Kabupaten Tangerang. Universitas Indonesia Esa Unggul.

9. Djestawana, I.G.G., 2012. Pengaruh Pengembangan Organisasi, Kepemimpinan, Jenjang Karir terhadap Kepuasan Kerja dan Kinerja Pegawai Puskesmas. Jurnal Kesehatan Masyarakat Nasional, 6(6), pp.261265

10. Sudigdo, S. \& Ismael, S., 2008. Dasar Dasar Metodologi Penelitian Klinis Edisi III., Jakarta: CV Sagung Seto.

11. Duhri, A.P., 2012. Kinerja Petugas Puskesmas Dalam Penemuan Penderita TB Paru Di Puskesmas Kabupaten Wajo.

12. Sukrajap, Muhammad Ali, 2016. Pengaruh Kepemimpinan Transformasional terhadap Kepuasan Kerja dan Komitmen Organisasional dengan Mediasi Pemberdayaan Psikologi. Jurnal Psikologi, Vol. 12, pp 22-45.
13. Robbins, S.P., 2008. Perilaku Organisasi Edisi Kedua., Jakarta: PT Prehallindo

14. Manulang, 2005. Dasar Dasar Manajemen Edisi XVII., Yogyakarta: Gadjah Mada University Press

15. Sudarsono, H., 2010. Pengaruh Karakteristik Pekerjaan dan Karateristik Organisasi terhadap Kepuasan Kerja Pegawai pada Puskesmas Kecamatan Sumbermanjing Wetan di Malang. Jurnal Aplikasi Manajemen, 8(3), pp.847-858

16. Robbins, S.P., 2003. Perilaku Organisasi Bahasa Ind., Jakarta: PT Indeks.

17. Mathis, R.L. \& Jakson, J.H., 2001. Manajemen Sumber Daya Manusia Edisi I., Jakarta: PT Salemba Emban Patria.

18. Adman, S., 2004. Kepemimpinan dan Produktivitas Kerja (Studi Tentang Perilaku Kepemimpinan dalam Menunjang Produktivitas Kerja Karyawan di Pondok Pesantren Daarut Tauhid Bandung). JPIS FPIPS UPI.

19. Wijaya, I.B.W., 2007. Pengaruh Kompensasi, Pengembangan Karir, Kepemimpinan dan Lingkungan Kerja terhadap Kinerja Pegawai Negeri Sipil di Rumah Sakit Umum Pusat Sanglah. Universitas Udayana

20. Hasibuan, M.S., 2001. Manajemen Sumber Daya Manusia Edisi Revi., Jakarta: PT Bumi Aksara

21. Hasanah, A. et al., 2012. Kepemimpinan, Malang.

22. Drumond, H., 1991. Effective Decision Making T. Hermaya, ed., Jakarta: PT Gramedia Pustaka Utama.

23. Sasongko, Totok., 2008. Pengaruh gaya kepemimpinan terhadap Prestasi Kerja Karyawan pada KPRI Bima Jaya Pasuruan. Jurnal Sarjana Fakultas Ekonomi Universitas Tribhuwana Tunggadewi, Malang.

24. Wibowo, 2009. Manajemen Kinerja, Jakarta: PT Raja Grafindo Persada 